\title{
A Comparative Analysis of the Energy Return on Investment of Organic and Conventional Icelandic Dairy Farms
}

\author{
Reynir Smari Atlason ${ }^{1,2^{*}}$, Karl Martin KJaerheim, Brynhildur Davidsdottir ${ }^{2}$, \\ KRISTIN VALA RagnaRSDOTTIR ${ }^{3}$ \\ ${ }^{1}$ University of Iceland, School of Engineering and Natural Sciences, Faculty of Industrial Engineering, Mechanical \\ Engineering and Computer Science, Hjardarhagi 6, 107 Reykjavik, Iceland. E-mail: rsa3@hi.is ("corresponding author) \\ ${ }^{2}$ University of Iceland, Faculty of Environment and Natural Resources. Oddi, Scemundargata 2101 Reykjavik, Iceland \\ ${ }^{3}$ University of Iceland, Institute of Earth Sciences, Askja, Sturlugata 7, 101 Reykjavik, Iceland
}

\begin{abstract}
This study compares the energy return on investment (EROI) of organic and conventional farms in Iceland. It examines which farming method returns the highest amount of edible energy to society relative to the input required. Twenty farms were studied: two organic and 18 conventional. Real data were gathered directly from five farms (including both of the organic farms in the study). Further data from 15 conventional dairy farms of different sizes were collected from a database maintained by the Icelandic Farmers Association. One of the organic farms studied (Org1) was found to have an EROI of 2.68, whereas two conventional farms used as controls for comparison (Con1-a and Con1-b) had EROIs of 0.60 and 0.69 , respectively. The second organic farm (Org2) had an EROI of 0.55 , versus the control farm ratio of 0.27 . On average, large ( $<170$ hectares) conventional dairy farms had an EROI of 0.65 , while medium ( $<70$ hectares) and small ( $<40$ hectares) conventional farms had average EROIs of 0.56 and 0.50 , respectively. This limited analysis suggests that organic dairy farms may provide better EROIs than conventional farms, but that their dairy yields per hectare are lower.
\end{abstract}

Keywords: Energy analysis, EROI, Agriculture

\section{YFIRLIT}

Samanburður á orkuarðsemi (EROI) lifrrenna og hefðbundinna islenskra kúabúa.

pessi rannsókn ber saman orkuarðsemi (EROI) lífrænna og hefðbundinna íslenskra kúabúa. Athugað er hvaða landbúnaðaraðferð skilar mestri orku til samfélagsins á móti peirri orku sem notuð er. Tuttugu býli voru rannsökuð, par sem raungögn voru fengin beint frá 5 býlum. Gögn sem lýsa 15 tilviljanakenndum kúabúum af mismunandi stærðum voru einnig fengin úr búreikningum. Niðurstöður sýna að fyrra lífræna býlið (Org1) skilaði EROI 2.68, hefðbundin samanburðarbýli pess skiluðu 0.60 (Con1-a) og 0.69 (Con1-b). Hitt lífræna býlið (Org2) skilaði EROI 0.55. Samanburðarbýli pess (Con2) skilaði EROI 0.27. EROI meðaltal stórra hefðbundinna býla valin af handahófi var 0.65 , meðaltal miðlungs stórra býla var 0.56 og meðaltal lítilla býla var 0.50 . Pessi rannsókn gefur til kynna að lífræn kúabú gefi betri orkuarðsemi en hefðbundin býli en að uppskera á hvern hektara sé minni. 


\section{INTRODUCTION}

Increasing food demand is one of the greatest challenges the agricultural sector will face in the coming years (Pimentel et al. 1999). The Food and Agriculture Organization of the United Nations (FAO) (2009) predicts that a $50 \%$ increase in food production will be necessary by 2050 to satisfy the expected food demand. Conventional oil and phosphate rock production (on which most modern agriculture is completely dependent) is also peaking (Campbell \& Laherrere 1998, Ragnarsdottir et al. 2012, Sverdrup et al. 2013). In the long run, fertilizers and other fossil fuel products that are used extensively in conventional farming (e.g. pesticides and herbicides) may increase significantly in price. Conventional agriculture is dependent on fossil fuels to produce its bioenergy output (Pimentel et al. 1973, Pimentel et al. 2005, Alam et al. 2005). The use of such energy also has various unfavourable environmental impacts. Therefore, the need to assess agricultural practices in terms of their environmental impacts and energy use is great, and this kind of analysis would assist in determining which agricultural method is most likely to sustain the growing world population with the least impact on the environment. By analysing the edible energy returns relative to energy investment of various agricultural practices, it is possible to evaluate which methods provide the best returns. Such studies can also help to determine how energy efficiency can be improved in terms of generating higher yields relative to the amount of energy input required to create a given product. The aim of the study is to examine the energy costs and returns involved in modern agriculture with a special emphasis on comparing organic and conventional farming systems in Iceland.

\section{Energy use in agriculture}

Fertilizer use has been the dominant factor in modern agriculture that has allowed for much higher yields, especially in cereal production (Bumb \& Baanante, 1996). As the production of fertilizers is highly energy consuming, the use of fertilizers contributes significantly to the overall energy consumption of conventional farms (Stölze et al. 2000, Pimentel et al. 2005, Johnson et al. 2007). The Soil Association concludes that for every calorie of conventionally produced, processed and shipped food approximately 10 calories of oil are required (Soil Association, 2008). Approximately 5.2 million kcal $(21,757$ $\mathrm{MJ})$ were used in the production of corn (maize) per hectare on conventional farms, whereas the energy needed per hectare was $28 \%$ lower for organic animal farms and $32 \%$ lower for organic legume farms producing similar yields (Pimentel et al. 2005). Pimentel concludes that the energy required per hectare for conventional farms was significantly higher than that of organic farms, due primarily to the input of chemical fertilizers, especially nitrogen. Pimentel (2009) has also shown that with better manure management, a significant amount of energy could be saved in the form of nitrogen fertilizers. Cederberg \& Mattsson (2000) examined the differences in the overall environmental impact of milk production between conventional and organic farms in an LCA study (LCA, or Life Cycle Assessment, is a methodology used to investigate the environmental impact of products or services throughout their lifetimes). They found that 3,550 MJ were used per 1000 $\mathrm{kg}$ of energy corrected milk (ECM) in the conventional system, while 2,511 MJ were used in the organic system (ECM is a unit regularly used by the dairy industry, which includes both the fat and protein content of the milk). Similarly, Reefsgard et al. (1998) found that $2,160 \mathrm{MJ}$ were used to produce $1000 \mathrm{~kg}$ of milk in the Danish organic farming system, versus 3,340 MJ (54\% higher) for conventional Danish dairy farms. The study further strengthened the conclusions of similar studies that showed that organically managed farms were more energy efficient than conventional farms (Stölze et al. 2000, Pimentel et al. 2005, Johnson et al. 2007). In a study that also used the LCA methodology, Haas et al. (2001) surveyed 18 grassland farms for environmental impacts and energy use, comparing three types of grass farming: intensive, extensive (or low-input farms) and organic. On average, the intensive farm system used 4,482 
GJ per hectare in the form of lubricants and oil; the low input extensive farms used 4,117 GJ per ha ( $9 \%$ lower), whereas the organic farm system used a significantly smaller amount, or 3,439 GJ per hectare $(23 \%$ lower). This result illustrates the lower consumption of petroleum products associated with organic agriculture. Gomiero et al. (2008) found that organic farms saved more energy than conventional ones. Their report summarizes various studies that compare the output/input ratio associated with numerous farming activities and clearly shows that in U.S. wheat production organic farms are $29-70 \%$ more efficient than conventional farms. In their literature review, Stölze et al. (2000) found that organic farming consistently uses less energy per hectare and that the biggest contributor to the differences in energy consumption observed between organic and conventional farms is the absence of fertilizers, pesticides and the lower use of feed in organic agriculture. Stölze et al. (2000) showed that organic farms could also expect to expend less energy per ton of output produced. This was found to be true for winter wheat, citrus and olive production; in these cases, organic farms used between $21 \%$ and $45 \%$ less energy per ton of output compared to conventional farms. According to the findings by Stölze et al. (2000), Pimentel et al. (2005) and Johnson et al. (2007), fertilizers are a significant contributor to higher energy use on conventional farms

As was clearly illustrated by Stölze et al. (2000) in their thorough review of the research literature, organic farms can be expected to provide better EROIs than conventional farms. This is also the case since research shows that organic farms require lower energy inputs in their operations. Studies such as this one are intended to shed more light on the potential benefits of organic farming methods and the EROI methodology is very suitable for this purpose. However, this is only half the story, as the trade-off comes in the form of the lower yields per hectare for organic farms. Iceland is an island with a rather limited area of land suitable for farming, producing only a portion of the overall food energy consumed by its inhabitants, highlighting the importance of yield per area.

Energy return on investment (EROI) in agriculture

Energy return on investment (EROI) is a method of examining the energy return from an energygenerating process relative to the energy used to derive the energy end products. It considers the energy taken from society and how much of it is subsequently returned to society. Charles Hall (1972) originally coined the methodology and used it to assess the evolutionary advantage of migration in fish. It was then applied to the energy sector when Hall used the method to assess petroleum extraction (Hall \& Cleveland, 1981). Ozkan et al. (2004) examined the energy output/input ratio from 1975 until 2000 in the Turkish agricultural sector, and found that it decreased from 2.23 in 1975 to 1.18 in 2000 , indicating a significant decline in energy return on investment over time. Pracha and Volk (2011) showed that wheat production in Pakistan had an EROI of around 2.9 and experienced a decline of $21 \%$ between 2000 and 2006 . Refsgaard et al. (1998) assessed the energy input versus output at 14 organic and 17 conventional farms in Denmark. They found that conventional dairy production exhibited higher energy input intensity due to the use of feed, but also delivered higher yields per hectare. However, the increased yields were not sufficiently higher to compensate for the amount of extra energy used compared with organic practices. Pimentel et al. (1973) clearly showed how rapidly the dependency on fossil energy in agriculture grew in only 25 years between 1945 and 1970 , mainly because of the introduction of nitrogen fertilizers.

In his study of U.S agriculture, Cleveland (1995a) showed two trends that occurred from 1910 to 1990 that related directly to energy consumption in farming. One was the shift from gasoline tractors to diesel-powered tractors; the second was a shift to more electricitybased methods where the electricity consumed by farming activities represented nearly $11 \%$ of the total U.S. electricity consumption by 
1990. Cleveland also observed a 33\% decline in fossil fuel and electricity use from 1978 to 1990, following a peak in 1978, when farming activities consumed 4.4 exajoules, or $5 \%$ of the primary energy used in the US (Cleveland, 1995a). Cleveland (1995b) examined direct as well as indirect energy use in his assessment and thereby confirmed that it was feasible to include indirect energy when conducting a study of this kind. Cleveland considers direct energy to be fossil fuels and electricity used on the farms to produce output. He divided indirect energy into two categories: first, the energy used to produce the farm machinery, chemicals, fertilizers and services needed by agriculture; second, the fuel used to produce the electricity used on the farms (Cleveland, 1995b).

Methodologies used to calculate EROI often differ, making comparisons difficult. This can be attributed to the fact that researchers have not followed a standard methodology and that the understanding about indirect energy use has increased in recent years (Schramski et al. 2013). This leads to lower EROI results, which can be interpreted as evidence that farming is becoming more energy intensive, although this does not need to be the case. There is some recent evidence that EROIs for food production in US agriculture have stopped declining and may be increasing. However, this may have more to do with changes in what the farms are producing than intrinsic efficiency (Hamilton et al. 2013).

EROI values in the present study were calculated according to the output/input methodologies of Cleveland (1995), Refsgaard et al. (1997) and Ozkan et al. (2004), even though different terminologies were used in previous studies (e.g. process analysis or EROI). The focus of the study presented was farms in Iceland, where the energy return on investment of conventional farms was compared to that of organic farms. This type of study had never before been undertaken in Iceland.

\section{MATERIALS AND METHODS}

General descriptions of the farms in question

The five farms included in this study are all located in the south-western part of Iceland, the centre of most of the country's rather limited agricultural production. Control farms were located near the study farms, as this allowed for comparison of the operations with the same natural geological, geographical, climatic and environmental conditions. For the purposes of this study, a control farm was a conventional farm located near an organic farm that was suitable for a comparison of this kind. The first organic farm (Org1), and its control farms (Con1-a and Con1-b), are located in Kjósahreppur [Kjósa District], SW Iceland. The second organic farm (Org2) and its control farm (Con2) are located in Skeiða- and Gnúpverjahreppur, in the southern lowlands of Iceland. All the farms are within a 1.5-hour drive from Iceland's capital area but are located in different directions. One of the largest factors that differentiated the farms in Kjósahreppur (Org1, Con1-a and Con1-b) from the farms in Skeiða- and Gnúpverjahreppur (Org2 and Con2) was that in Kjósarhreppur the water used for space heating was electrically heated whereas Skeiða- and Gnúpverjahreppur has abundant geothermal water, which is used for heating houses and greenhouses. It was not possible to include more organic farms because of the limited numbers of such farms in Iceland.

\section{Organic farm Orgl}

This organic farm had 55 hectares of cultivated land and is located in Kjós, in south-western Iceland. The farm's livestock consisted of 70 head of cattle, which were kept in a $648 \mathrm{~m}^{2}$ cow shed. The owners of the farm also maintained a combined area of $80 \mathrm{~m}^{2}$ of greenhouses, where various vegetables were produced, but only for their own consumption. The farm had four operating tractors: three Massey Ferguson's (50 $\mathrm{hp}, 75 \mathrm{hp}$ and $90 \mathrm{hp}$ ), and one Fent (125 hp). There were two full-time employees handling the daily farm activities (Oddsson, 2011). In addition, this organic farm used a technique generally referred to as agroforestry, in which trees are planted around their cultivated land both to shelter their crops, livestock and soil from wind erosion and to further strengthen the nutrient composition of the soil. The farm made 
its own green manure, which was applied to the land. The milk produced by the farm's cows went to a specialized organic dairy owned by the farm, which produced a variety of organic dairy products.

\section{Control farm Con1-a}

Con1-a was a 56-hectare (cultivated land) conventional farm, located in Kjós in the southwestern part of Iceland. Livestock consisted of 143 head of cattle, 18 sheep and 9 horses. There was no greenhouse, nor any vegetable production as their main focus was on milk production. They used 9 operating tractors (no further information was provided) and on average 3 people worked full-time at the farm.

\section{Control farm Con 1- $b$}

Con1-b was a 32-hectare (cultivated land) conventional farm, located in Kjós in the southwestern part of Iceland, and was the second control farm of the organic farm, Org1. Con1-b was adjacent to Org1 and located closer to it than Con1-a, making it perhaps a more ideal control farm for the organic farm due to soil similarities, and hence its inclusion. Con1-b had 42 head of cattle and 120 sheep. They did not have a greenhouse, nor did they produce any vegetables, as their main focus was on milk and lamb production. The farm maintained three operating tractors (no further information was provided). The farm had up to nine people working on it, but not all were full-time. The amount of delivered working man-days was 712 for the year 2010 .

\section{Organic farm (Org2)}

The organic (Org2) farm was located in Skeiðaand Gnúpverjahreppur [District] in the southern part of Iceland. It consisted of 220 hectares of land, of which 40 hectares were cultivated. Livestock included 18 cows, 22 head of young cattle, 1 bull, 25 sheep and 30 chickens. The two main barns on the premises covered an area of $850 \mathrm{~m}^{2}$ and $700 \mathrm{~m}^{2}$. In addition, the farm had three greenhouses with a collective area of $300 \mathrm{~m}^{2}$ where various root vegetables were cultivated, including potatoes, carrots, beetroots and turnips. The farm had four operating tractors: one Carrard (68 hp), one Steyr (70 hp) and two Case tractors (75 hp and $100 \mathrm{hp}$ ).

\section{Control farm Con 2}

The control farm used to evaluate the second organic farm (Org2) was a 110-hectare (cultivated land) conventional farm; its total land area amounted to 300 hectares. Con2 was located in Skeið- and Gnúpverjahreppur in the southern part of Iceland, adjacent to the organic farm (Org2). Livestock included 155 sheep, 135 head of cattle and 16 horses. Con2 had two barns with a collective size of $1450 \mathrm{~m}^{2}$. The farmers did not operate a greenhouse, nor did they produce any vegetables, as their main focus was on dairy and beef production. They had a robot to handle the milking activities, and according to the farmer, the cows did not go outside. They had five operating tractors (no further information was provided) and seven uncategorized machines. At this farm, ten hours of work were conducted every day, 365 days a year.

\section{Other conventional farms}

For a better comparison, and a better sample size, data were gathered from the Farmers Association of Iceland on 15 random dairy farms. The information gathered fitted deliberately under the same system boundary as the farms we visited. The farms are divided into three categories: large, medium and small, depending on the area of cultivated farmland each farm contains. Small farms have $<40$ hectares of cultivated land, medium-sized farms have 40 to 70 and large operations have 70 to 170 ha. The exact location of the farms in the database, however, is unknown, but the results from these farms shed further light on the level of energy returns associated with Icelandic dairy production. Data for the energy inputs and outputs of these farms were retrieved from a database produced by the Farmers Association of Iceland. Energy outputs from these farms included milk, beef and lamb. Energy inputs considered in the study included feed, fertilizers, petroleum, gasoline and electricity. It should be 
Table 1. Dairy farm data collected from the Icelandic Farmers Association database. Note that Farm 4s was missing electricity consumption data, skewing its results. Numbers are in GJ for products.

\begin{tabular}{|c|c|c|c|c|c|c|c|c|c|c|c|c|c|}
\hline $\begin{array}{l}\text { Farm } \\
\text { from } \\
\text { database }\end{array}$ & & Milk & $\begin{array}{r}\text { Beef } \\
\text { (calves) }\end{array}$ & Beef & $\begin{array}{r}\text { Beef } \\
\text { (Cow) }\end{array}$ & Lamb & Feed & Fertilizer & Gas & Diesel & Electricity & EROI & $\begin{array}{r}\text { Yield } \\
\text { per ha } \\
\text { (GJ) }\end{array}$ \\
\hline $3 \mathrm{~s}(28)$ & & 153.6 & & 4.0 & 7.7 & 8.5 & 88.3 & 164.8 & & 112.1 & 119.3 & 0.35 & 6.2 \\
\hline $4 \mathrm{~s}(20)$ & & 170.0 & & 2.8 & 7.9 & & 116.4 & 73.0 & & 28.8 & & 0.82 & 9.0 \\
\hline $5 \mathrm{~s}(37)$ & & 148.7 & & 2.9 & 1.7 & 11.2 & 104.4 & 180.9 & & 39.1 & 157.5 & 0.34 & 4.4 \\
\hline 6s (24) & & 211.2 & & 3.2 & 8.3 & & 189.1 & 116.6 & & 74.4 & 260.5 & 0.34 & 9.3 \\
\hline $7 \mathrm{~s}(23)$ & & 155.7 & & 1.7 & 2.8 & & & & & 58.8 & 192.5 & 0.63 & 7.0 \\
\hline $8 \mathrm{~m}(41)$ & & 466.5 & & 27.4 & 11 & & 351.3 & 578.9 & & 353.7 & 198.9 & 0.34 & 12.3 \\
\hline $9 \mathrm{~m}(50)$ & & 646.3 & & 3.8 & 12.2 & & 368.4 & 579.0 & & 110.5 & 197.8 & 0.52 & 13.2 \\
\hline $10 \mathrm{~m}(65)$ & है & 571.0 & & 12.5 & 13.6 & 言 & 348.4 & 603.0 & & & 232.5 & 0.50 & 9.2 \\
\hline $11 \mathrm{~m}(62)$ & & 630.0 & 1.7 & 1.6 & 19.1 & & 213.6 & 480.4 & & 64.0 & 177.3 & 0.69 & 10.5 \\
\hline $12 \mathrm{~m}(64)$ & & 491.3 & 3.4 & 1.1 & 15 & & 262.5 & 19.5 & & 262.9 & 151.7 & 0.73 & 8.0 \\
\hline $131(90)$ & & 1253.0 & & 31.1 & 40.4 & & & 1684.1 & 18.1 & 335.4 & 161.1 & 0.60 & 14.7 \\
\hline $141(90)$ & & 1128.2 & 5.1 & & 54.5 & & 1915 & 804.4 & 7.0 & 367.4 & 679.1 & 0.31 & 13.2 \\
\hline $151(166)$ & & 1238.7 & & 45.9 & 23.4 & 48.2 & & 1329.2 & 3.1 & 370.0 & 807.2 & 0.54 & 8.2 \\
\hline $161(90)$ & & 1037.6 & 0.3 & 2.1 & & & 754.2 & & & 295.1 & 202.8 & 0.83 & 11.6 \\
\hline $171(117)$ & & 1624.1 & 1.9 & 35.6 & & & 834 & 74.2 & & 225.6 & 581.1 & 0.96 & 14.2 \\
\hline
\end{tabular}

noted, however, that electricity data were not retrieved from the database farm " $4 \mathrm{~s}$ ", skewing the results for that particular farm. Table 1 illustrates the inputs and outputs from the farms retrieved from the Farmers Association of Iceland database.

\section{System boundaries}

Clear boundaries have to be set to maintain consistency between the farms studied. All energy inputs (energy delivered to the farms in the form of oil, electricity, hot water and/or synthetic fertilizers) and the resulting energy outputs (in the form of produced products) were accounted for in the study (see Figure 1). If products consumed on the farm during farm operations or by animals (such as feed) were generated on the farm, these products were considered as intermediates which do not cross the farm's system boundaries and were therefore not included in the calculations. The energy used to produce and package fertilizers was accounted for and can be seen as the only indirect input. Since the energy used to produce feed for cattle at given farms had been accounted for (in diesel, fertilizers, electricity, etc.), which eventually become manure, it can be stated that, in essence, the production of the manure had been accounted for. As a result, the energy contained in manure was not included because inclusion would lead to double accounting. since the production of the manure was accounted for in the form of grass and feed production that eventually becomes manure. The energy needed for the production of chemical fertilizers was accounted for as well; here the values for the production intensities were compiled from the scientific literature (Fluck, 1992). The transport of goods to and from the farms was excluded in this study, since the research question focused on the EROI related to the farming methods used and/or 


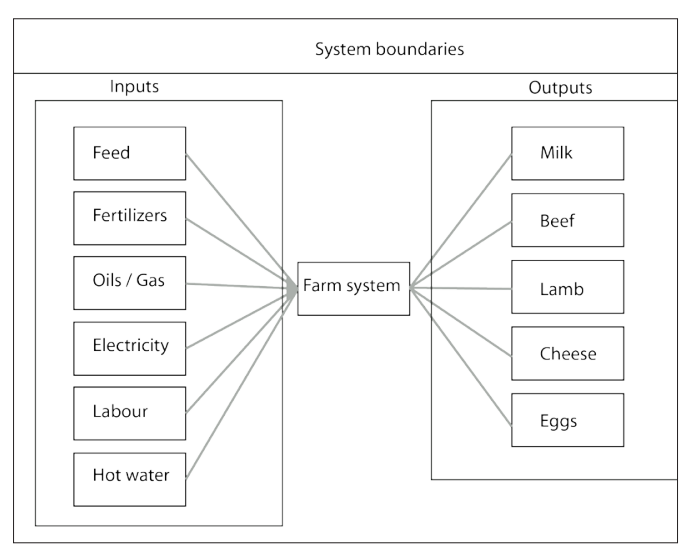

Figure 1. Explanation of system boundaries. Factors used in the EROI calculations are shown inside the box delineating the farm's system boundaries.

specific land-management practices employed. If transport had been included, the results would have varied between locations and mask the differences between different farming practices. Geothermal water in Iceland is commonly used to heat greenhouses (Gunnlaugsson et al. 2003), and it is therefore possible to produce products year round through the use of artificial lighting during the winter. Geothermal water used in the greenhouse at Org2, however, was excluded as the produce was only for personal consumption. To compensate for the heating of the farmhouse, average values were used (BERR, 2007). Also, energy derived directly from the sun was excluded, since "radiant energy from the sun is practically infinite in total amount" (Refsgaard et al. 1998) and would be similar per hectare on the farms that are being compared. Figure 1 represents the system boundaries of this study.

\section{Calculations}

The energy output was calculated from each farm by multiplying the mass of products the farm produced times the energy density of the food materials themselves and compared with the industrial energy used in the production process. Data were collected on site from two organic farms and three conventional farms to assess the EROI. Data were then gathered describing output and energy use for the 15 non- organic dairy farms from the database managed by the Farmers Association of Iceland. These farms varied in size but were all conventional contemporary farms. A summary of the energy flows can be seen in Figure 1.

\section{EROI method used in this study}

In this study, the following equation was used to assess the EROI:

$$
\mathrm{EROI}=\sum \mathrm{ED}_{\text {out }} /\left(\sum \mathrm{ED}_{\mathrm{in}}+\sum \mathrm{p}_{\mathrm{k}} \mathrm{m}_{\mathrm{k}}\right)
$$

where $E D_{\text {out }}$ represents the energy content of the products exported from the farms. $E D_{\text {in }}$ is the amount of direct input energy (Mulder \& Hagens, 2008). As indirect energy was accounted for in the form of fertilizers, $p_{k}$ represents the amount of a certain type of fertilizer, whereas $m_{k}$ is the embodied energy of that particular fertilizer. Thus, the direct energy of the products entering the farms was accounted for, as well as the energy used to produce any major input to the farming activities, such as fertilizer. All products leaving the farms were similarly accounted for. The energy content of manure was excluded as the energy used to create the manure had already been accounted for in the form of input energy (e.g. fertilizers) that eventually went to feed the animals. As this method excludes the transport of materials to and from the farm and focuses only on the farm, regardless of its location, it can be stated that this study utilized EROI $_{1, \mathrm{~d}}$, according to the standards set out by Murphy et al. (2011), meaning that only direct inputs and outputs were accounted for. In summary, the direct energy and material inputs and outputs, except for the fertilizers where the embodied energy was accounted for, were taken into account.

\section{Data collection}

This section outlines the manner in which the energy content of various products was calculated and how data were collected. The assumptions made are also outlined below.

\section{Hot Water}

Geothermal water and heated water were 
significant contributors to the total energy used at one farm. The equation used to account for the energy embodied in it is as follows:

$$
Q_{\text {water }}=V * \rho * C_{p} * \Delta T
$$

where $Q_{\text {water }}$ is the amount of thermal energy extracted from the district heating system at the farm (in $\mathrm{kJ}$ ), $V$ is the total annual volume of hot water used in $\mathrm{m}^{3}, \rho$ the density of the hot water, $990 \mathrm{~kg} \mathrm{~m}-3, C_{p}$ is the specific heat of the water, $4.18 \mathrm{kj} \mathrm{kg-1}{ }^{\circ} \mathrm{C}-1$, and $\Delta T$ is the temperature difference between the inlet and outlet temperatures of the district heating water in ${ }^{\circ} \mathrm{C}$. The thermal energy leaving the farm was subtracted from the thermal energy entering the farm and therefore the number determined in this calculation shows the energy consumed on the farm.

\section{Electricity}

Where the relevant information for electricity use was unavailable and only the amount paid for the electricity for a given year could be determined, an average price for electricity (derived from Rarik, 2011) was used to derive the quantity of KWh used at the farm. A correction was made to account for the subsidized price of energy to the farm; therefore the following was assumed: the full price of one kWh was 6.32 ISK (Rarik, 2011). The Icelandic government subsidizes the electricity, paying 4.17 Icelandic krona (ISK) (to $2.15 \mathrm{ISK}$ ) to farms for up to $40,000 \mathrm{kWh}$. The price to obtain a watt-hour meter is 2,340 ISK per month (28,080 ISK per year). Equation 3 describes the $\mathrm{kWh}$ used on the farms with the factors described included:

$$
E=a+(x-y-a b) / z
$$

In this calculation, $\mathrm{E}$ is the amount of energy used by the farm in $\mathrm{kWh}$, a the total of $\mathrm{kWh}$ subsidized by the government, $\mathrm{b}$ is the price for 1 $\mathrm{kWh}$ after subsidizing, $\mathrm{x}$ is the total amount paid by the farm on an annual basis, $y$ is the annual cost paid by the farm to obtain the electric meter (this is relevant to receive an accurate amount of
$\mathrm{kWh}$ ), and $\mathrm{z}$ is the full price for $1 \mathrm{kWh}$ without subsidization. This equation gives inaccurate results if the total amount for the farm does not exceed the total amount of subsidized electricity available through the government. This can be seen only if the numerator becomes negative. In that case, the following equation is used:

$$
\mathrm{E}=(\mathrm{x}-\mathrm{y}) / \mathrm{b}
$$

\section{Oil}

The exact quantity of diesel purchased was not always known, but rather the monetary value of the diesel purchased. Since the price of diesel fluctuates rapidly, it was difficult to determine the exact amount used by a farm. To address this issue, the average price for a litre of diesel was obtained from Skeljungur (Shell Iceland) (2010) and used as a reference price. The price per litre for diesel was 199.73 ISK in 2010.

\section{Feed, Hay and Algae}

Barley or hay is sometimes imported to the farms. The NorFor method was used to calculate the feed unit. According to NorFor, one FEm (feed unit) is equivalent to $6.9 \mathrm{MJ}$ per $\mathrm{kg}$ (Volden et al. 2006); $\mathrm{kg}$ of barley is taken as equivalent to 1.06 feed units and therefore the feed units in this study were calculated accordingly. According to NorFor $1 \mathrm{~kg}$ of barley contains 7.29 MJ per $\mathrm{kg}$ (Volden et al. 2006). If a farm supplied only the amount of roughage hay used, it was calculated according to the NorFor standard for hay, mixed meadow, which contains 4.89 MJ per $\mathrm{Kg}$ (NorFor, 2011). In some cases, farms were only able to supply the number of hay rolls used in a given year. Given that rolls can vary in size and content density depending on whether they are wet or dry, some assumptions had to be made. The difference between wet and dry hay rolls is particularly significant (unless they are extremely dry or wet) and the hay can therefore be calculated as $175 \mathrm{~kg}$ of dry roughage per $\mathrm{m}^{3}$. One roll is approximately $1.5 \mathrm{~m}^{3}$. One roll will contain approximately $265.5 \mathrm{~kg}$ of hay. The quality of hay, however, differed from farm to farm, but the quality was usually known and could therefore be provided by the farms. The 
method to calculate this is as shown in equation 5:

$$
\mathrm{XY} / \mathrm{Z}=\mathrm{Fem}
$$

where $\mathrm{X}$ is the average weight of dry hay in a single roll (265.5), $Y$ the number of rolls a given farm uses in a year, and $\mathrm{Z}$ the amount of hay equivalent to 1 feed unit. Whenever the quality of the hay was not known, it was assumed that one kilogram corresponded to $4.89 \mathrm{MJ}$ of energy, as quoted by NorFor (1 roll would equal 1,289.3 MJ). Algae flour, used as an animal feed supplement, was assumed to contain 2,130 kcal per kilogram, which is equivalent to $8.9 \mathrm{MJ}$ per $\mathrm{kg}$.

\section{Fertilizers}

Artificial fertilizers are used on a large scale in modern conventional agriculture and fertilizer production tends to be an energy intensive process. Therefore, it is crucial to include fertilizers in the EROI calculations. In this study the energy required to produce and package the specific elements contained in the fertilizers $(\mathrm{N}$, $\mathrm{P}$ and $\mathrm{K}$ ) was included (see Table 2) as derived by Fluck (1992). The fertilizer production values derived by Fluck (1992) are similar to the more recent numbers provided by Kim \& Dale (2005) and Pimentel \& Patzek (2008). Transport, however, was excluded, as were other purchased inputs, since the inclusion of transport numbers would divert the results from the farming methods and provide skewed results due to the location of the country. The primary

Table 2. World average energy use in fertilizer production and packaging in MJ/Kg. (Fluck, 1992) Shipping was intentionally excluded because of Iceland's remote location.

\begin{tabular}{lccc}
\hline & Nitrogen & Phosphate & Potassium \\
\hline Produce & 69.53 & 7.77 & 6.4 \\
Package & 2.6 & 2.6 & 1.8 \\
Total & 72.13 & 10.37 & 8.2 \\
\hline
\end{tabular}

macronutrients of fertilizers are nitrogen $(\mathrm{N})$, phosphate $(\mathrm{P})$ and potassium $(\mathrm{K})$. Even though fertilizers contain various other materials and nutrients, farms rely on these three chemicals and therefore the energy used to produce them is accounted for. Secondary macronutrients have been left out of the world average estimated by Fluck (1992) and were therefore not included in this study.

\section{RESULTS}

It is not clear from this analysis whether or not organic farms have a significantly and consistently higher EROI than conventional farms. The results from the most explicit tests suggest that the organic farms used less energy per unit output than the control farms, with one farm returning more energy to society than it consumed (Figure 2). The first organic farm examined had an EROI of 2.68 whereas the EROI measures of its control farms were 0.60 and 0.69. The second organic farm examined returned an EROI of 0.55, which was higher than its control farm, which returned an EROI of 0.27 . The results of the second organic farm were similar to the average values of the conventional farms. Thus, when compared to a group of conventional farms, the second organic farm had a lower EROI. In fact, most farms returned greater EROIs than the second organic farm (Figure 2). Further clarification of the inputs and outputs of the farms visited, as well as the EROI ratios, are given in Table 3. It can be concluded that the first organic farm (Org1) produced the highest EROI because of its relatively low consumption of electricity and diesel fuel (3000 litres) when compared to its output. The absence of synthetic fertilizers also contributed to the organic farm's positive EROI. Con1-a, located close to the organic farm, was of similar size (56 hectares of cultivated land) yet used 7,565 litres of diesel fuel, more than double the amount used at the organic farm. The results from most of the farms visited and studied more carefully were similar to the second group of conventional farms (excluding the first organic farm). On average, small farms in the second group had an EROI of 0.50, medium farms an EROI of 


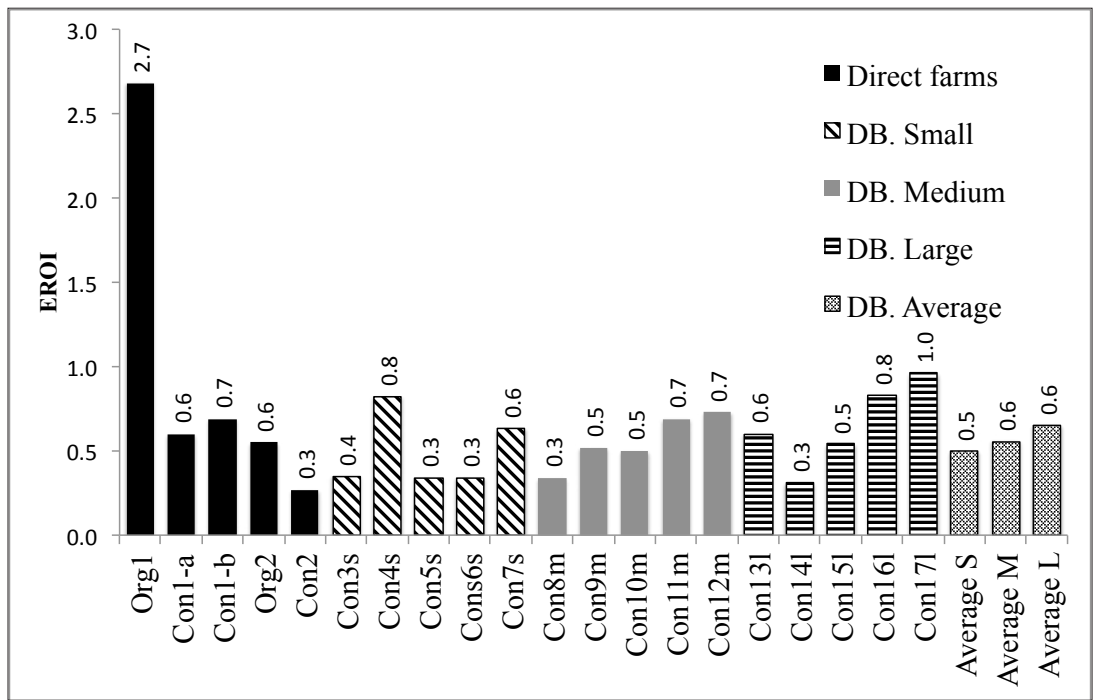

Figure 2. EROI results from the farms studied. Data for the first five farms were collected on site; the data for the following farms were gathered from the Icelandic Farmers Association database. $\mathrm{S}$ represents small farms, $M$ represents medium sized farms and $\mathrm{L}$ represents large farms. DB represents data gathered from the database.

Table 3. Specific inputs and outputs on the farms visited. All values are in GJ. Note that one of these farms heated exclusively with heated water, while the other farms observed use of electricity.

\begin{tabular}{|c|c|c|c|c|c|}
\hline & Org1 & Con1-a & Con1-b & Org2 & Con2 \\
\hline \multicolumn{6}{|c|}{ Input } \\
\hline Algae flour & 4.45 & & & & \\
\hline Labour & 5.5 & 5.6 & 8.2 & 8.2 & 1.1 \\
\hline Diesel & 108 & 272.3 & & 36 & 180 \\
\hline Electricity & 47.6 & 392.8 & 137.7 & 189.6 & 317.5 \\
\hline Hot water & & & & & 1088 \\
\hline Fertilizers & & 647.4 & 208.9 & & 973.6 \\
\hline Purchased feed & & 873.7 & 123.5 & & 520.9 \\
\hline Total & 165.5 & 2192 & 478.3 & 335.9 & 3081.2 \\
\hline Input per ha. & 3.01 & 39.14 & 14.95 & 8.4 & 28.01 \\
\hline \multicolumn{6}{|c|}{ Output } \\
\hline Milk & 429 & 1274.9 & 300.3 & 101.8 & 791.2 \\
\hline Cheese & & & & 13.6 & \\
\hline Beef & 14.3 & 44.2 & 5.7 & 6.3 & 29.8 \\
\hline Lamb & & 5 & 24.7 & 4.4 & 16.7 \\
\hline Eggs & & 0.9 & & 2.1 & \\
\hline Total & 443.3 & 1325.2 & 330.7 & 128.5 & 837.9 \\
\hline Yield per ha. & 8.06 & 23.64 & 10.34 & 3.21 & 7.61 \\
\hline EROI & 2.68 & 0.6 & 0.69 & 0.55 & 0.27 \\
\hline
\end{tabular}




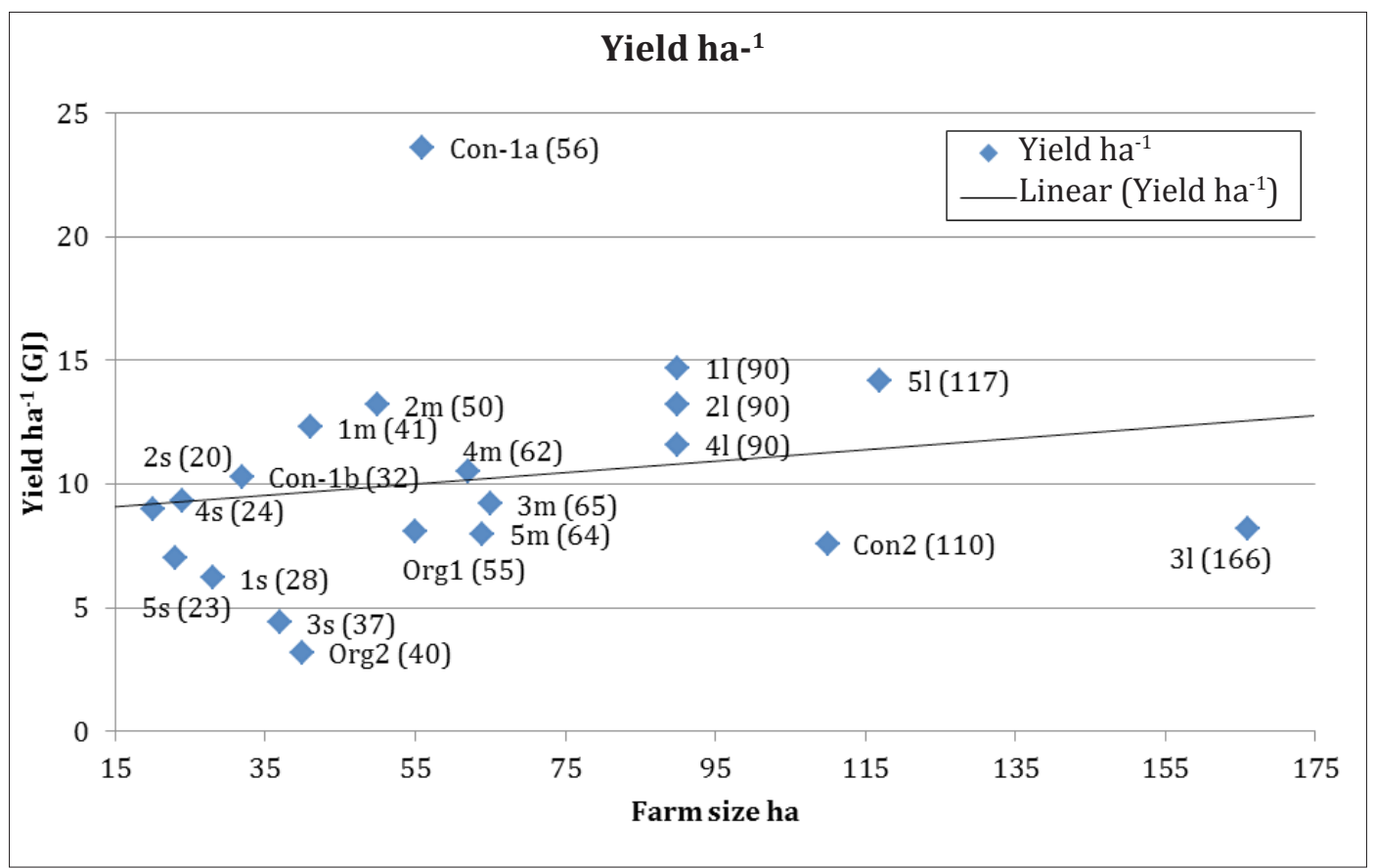

Figure 3. Yield per hectare from the farms under study. Numbers in parentheses represent the area of cultivated land on the farm.

0.56 and large farms showed an average EROI of 0.65 . All of the 15 conventional farms had EROIs that were lower than the highest EROI of the organic farms, although many had higher EROIs than the second organic farm (Figure 2). In terms of the yield per hectare, it was evident that the organic farms had relatively low yields when compared to the conventional farms. In fact, the conventional farm Con1-a had the best yield per hectare of all the farms studied. Figure 3 shows the yield per hectare of the farms, where farms are listed in an ascending order according to the cultivated land area of each farm.

\section{DISCUSSION}

Approximately 5,000 kWh were added to the Org2 electric consumption (18,000 MJ) to account for any geothermal hot water used at the farm (BERR Energy Trends, 2007).

The conventional farm Con1-b consumed and delivered similar amounts of energy compared to Con1-a. As has been shown in previous studies (Stölze et al. 2000, Pimentel et al. 2005, Johnson et al. 2007), fertilizers contributed significantly to the total energy consumption of the control farms (31\% at Con2, $29 \%$ at Con $1-$ a and $43 \%$ at Con1-b). At the Org2 farm, a lot of the energy consumed was from the hot water used in the greenhouses. For the purpose of this study, it is logical to omit the geothermal water for greenhouse heating at the Org2 farm because the control farm had no greenhouses. The electricity needed to heat the Org2 farmhouse was then estimated.

The EROI results obtained in this study were significantly lower than those observed by Ozkan et al. (2004). However, their study looked at the Turkish agricultural sector as a whole, rather than examining specific outputs. Wheat production may also provide a better EROI than dairy production.

Expanding the dataset with information from anonymous conventional farms further strengthened the analysis for the conventional 
farms, but having a larger dataset for the organic farms would have strengthened the analysis even further. Additional analysis evaluating EROI for each output product could provide a more precise comparative analysis, but it should be noted that this study merely provides an indication of the EROI in Icelandic dairy farming. The results presented may prove favourable for organic farming for a number of reasons, including the geographic location, type of output or the agricultural practices used on the farms in the study. Further studies are needed to shed further light on this issue.

\section{CONCLUSION}

The results from this study indicate that organic agriculture in Iceland may or may not have a favourable EROI when compared to conventional farms. This is mostly due to the absence of artificial fertilizers used by the organic farms. The findings, however, were limited by the small sample size of organic farms and the assumption that indirect energy used (e.g. for tractors and buildings) would be similar. Further analyses of organic farming in Iceland are needed to strengthen these findings. Such results are important in an era of increasing prices for fertilizers produced from oil and phosphate rock, which are impacted by resource depletion on a limited Earth.

\section{ACKNOWLEDGEMENTS}

The authors would like to acknowledge the farms that contributed to this research. This research was supported by the European Commission FP7 Collaborative Project "Soil Transformations in European Catchments" (SoilTrEC), Grant Agreement no. 244118.

\section{REFERENCES}

Alam MS, Alam MR, \& Islam KK 2005. Energy

flow in agriculture: Bangladesh. American Journal of Environmental Sciences 1, 213-220. doi: http:// dx.doi.org/10.3844/ajessp.2005.213.220

BERR 2007. Energy Trends, A national Statistics Publication. Accessed 06.14.2011 at www.berr. gov.uk/files/file43304.pdf

Bumb B, \& Baanante CA 1996. World trends in fertilizer use and projections to 2020. IFPRI. Accessed 06.30.2011 at http://www.ifpri.org/sites/ default/files/publications/vb38.pdf

Campbell CJ, \& Laherrère JH 1998. The end of cheap oil. Scientific American 278, 78-83.

Cederberg C, \& Mattsson B 2000. Life cycle assessment of milk production - A comparison of conventional and organic farming. Journal of Cleaner Production 8, 49-60. doi: http://dx.doi. org/10.1016/S0959-6526(99)00311-X

Cleveland CJ 1995a. The direct and indirect use of fossil fuels and electricity in USA agriculture, 19101990. Agriculture, Ecosystems and Environment 55, 111-121. doi: http://dx.doi.org/10.1016/01678809(95)00615-Y

Cleveland CJ 1995b. Resource degradation, technical change, and the productivity of energy use in U.S. agriculture. Ecological Economics 13, 185-201. doi: http://dx.doi.org/10.1016/09218009(95)00005-T

Fluck RC 1992. Energy Analysis for Agriculture. In: Fluck RC (ed.) Energy in Farm Production. Energy in World Agriculture, 6. Elsevier, pp. 45-52

Gomiero T, Paoletti MG, \& Pimentel D 2008. Energy and Environmental Issues in Organic and Conventional Agriculture. Critical Reviews in Plant Sciences 27, 239-254. http://dx.doi. org/10.1080/07352680802225456

Gunnlaugsson BR, Agustsson MA, \& Adalsteinsson $\mathbf{S}$ 2003. Sustainable use of geothermal energy in Icelandic horticulture. Paper presented at the International Geothermal Conference. Accessed 06.08.2011 at http://www.jardhitafelag.is/media/ PDF/S14Paper071.pdf

Haas G, Wetterich F, \& Köpke U. 2001. Comparing intensive, extensified and organic grassland farming in southern Germany by process life cycle assessment. Agriculture, Ecosystems 
\& Environment 83, 43-53. doi: http://dx.doi. org/10.1016/S0167-8809(00)00160-2

Hall CA 1972. Migration and metabolism in a temperate stream ecosystem. Ecology 53, 585-604. doi: http://dx.doi.org/10.2307/1934773

Hall CA, \& Cleveland CJ 1981. Petroleum drilling and production in the United States: Yield per effort and net energy analysis. Science 211, 576-579. doi: http://dx.doi.org/10.1126/science.211.4482.576

Hamilton A, Balogh SB, Maxwell A, \& Hall CA 2013. Efficiency of edible agriculture in Canada and the U.S. over the past three and four decades. Energies 6, 1764-1793. doi: http://dx.doi. org/10.3390/en6031764

Johnson JMF, Franzluebbers AJ, Weyers SL, \& Reicosky DC 2007. Agricultural opportunities to mitigate greenhouse gas emissions. Environmental Pollution 150, 107-124. doi: http://dx.doi. org/10.1016/j.envpol.2007.06.030

Kim S, \& Dale BE 2005. Life cycle assessment of various cropping systems utilized for producing biofuels: Bioethanol and biodiesel. Biomass and Bioenergy 29, 426-439. doi: http://dx.doi. org/10.1016/j.biombioe.2005.06.004

Mulder K, \& Hagens NJ 2008. Energy return on investment: Toward a consistent framework. AMBIO: A Journal of the Human Environment 37, 74-79. doi: http://dx.doi.org/10.1579/00447447(2008)37[74:EROITA]2.0.CO;2

Murphy DJ, Hall CAS, Dale M, \& Cleveland C 2011. Order from Chaos: A Preliminary Protocol for Determining the EROI of Fuels. Sustainability 3, 1888-1907. http://dx.doi.org/10.3390/ su3101888\#sthash.V8oucXde.dpuf

NorFor 2011. Hay, mixed meadow. Accessed 05.30.2011 at http://feedstuffs.norfor.info/Public/ DetailsView.aspx?id=006-0467

Ozkan B, Akcaoz H, \& Fert C 2004. Energy inputoutput analysis in Turkish agriculture. Renewable Energy 29, 39-51. doi: http://dx.doi.org/10.1016/ S0960-1481(03)00135-6

Pimentel D, Hurd LE, Bellott AC, Forster MJ, Oka IN, Sholes OD et al. 1973. Food Production and the Energy Crisis. Science 182, 443-449. doi: http://dx.doi.org/10.1126/science.182.4111.443

Pimentel D, \& Patzek T 2008. Ethanol production using corn, switchgrass and wood; Biodiesel production using soybean. In: Pimentel D (ed.) Biofuels, solar and wind as renewable energy systems. Springer, Netherlands, pp. 373-394.

Pimentel D, Hepperly P, Hanson J, Douds D, \& Seidel R 2005. Environmental, energetic, and economic comparisons of organic and conventional farming systems. BioSicence 55, 573-582. doi: http://dx.doi.org/10.1641/00063568(2005)055[0573:EEAECO]2.0.CO;2

Pimentel D, Pimentel M, Karpenstein-Machan M, Srzednicki GS, \& Driscoll RH 1999. Energy use in agriculture: An overview. In CIGR E-journal Collection, Vol. 1, 1-32. PDF file.

Pimentel D 2009. Reducing Energy Inputs in the Agricultural Production System. Monthly Review 61, 92-101.

Ragnarsdóttir K, Sverdrup H, \& Koca D 2012. Assessing long term sustainability of global supply of natural resources and materials. Sustainable Development-Energy, Engineering and Technologies-Manufacturing and Environment, 2013, 83-116.

Rarik 2011. Verðskrá fyrir dreifingu og flutning raforku. [Energy prices for distribution and transport of electricity] Reykjavik Rarik. Accessed 01.06.2011 at http://www.rarik.is/skjolrarik?D ocumentScreen $=$ detail\&cl $=364 \& \operatorname{ccs}=738 \quad$ [in Icelandic]

Refsgaard K, Halbergb $\mathbf{N}, \&$ Kristensenb ES 1998. Energy utilization in crop and dairy production in organic and conventional livestock production systems. Agricultural Systems 57, 599-630. doi: http://dx.doi.org/10.1016/S0308521X(98)00004-3

Schramski JR, Jacobsen KL, Smith TW, Williams MA, \& Thompson TM 2013. Energy as a potential systems-level indicator of sustainability in organic agriculture: Case study model of a diversified, organic vegetable production system. Ecological Modelling 267, 102-114. doi: http:// dx.doi.org/10.1016/j.ecolmodel.2013.07.022

Skeljungur 2010. Verðlistar. [Oil price list] Accessed 05.20.2011 at http://skeljungur.is/Einstaklingar/ Eldsneytisverd/Verdlistar [in Icelandic]

Soil Association 2008. An Inconvenient Truth about Food: Neither Secure nor Resilient. Bristol: Soil Association. Accessed 08.05.2011 at http://www. 
soilassociation.org/LinkClick.aspx?fileticket=Ett WlupviYA\%3D\&tabid=387

Stölze M, Piorr A, Häring A, \& Dabbert S 2000. The Environmental impacts of organic farming in Europe. Economics and Policy 6, 13-86

Sverdrup HU \& Ragnarsdottir KV 2011 Challenging the planetary boundaries II: Assessing the sustainable global population and phosphate supply, using a systems dynamics assessment model. Applied Geochemistry 26. 307-310. doi: http:// dx.doi.org/10.1016/j.apgeochem.2011.03.089

United States Department of Agriculture. Nutrient Data Laboratory. Accessed 05.14.2011 at http:// www.nal.usda.gov/fnic/foodcomp/search/

Volden H, Larsen M \& Mehlqvist M 2006 Orku- og próteingildi í fóðri - NorFor [Energy and protein contained in feed]. Freyr, 1(102), 7-9. [in Icelandic]

Manuscript received 17 November 2014

Accepted 21 May 2015 